\title{
Podstawy wolności narodu w nauczaniu Jana Pawła II*
}

\section{Ks. Zdzisław Struzik}

\section{Wprowadzenie}

Budowanie więzi społecznych pomiędzy narodami i pomiędzy naturalnymi związkami realizowanymi na różnych poziomach życia, takich jak: rodzina, szkoła, miasto i wieś oraz państwo, w którym zamieszkuje dany naród, wymaga przyjęcia podstawowych wartości moralnych, a szczególnie wolności. Wolność przynależy człowiekowi ze względu na jego godność. Człowiek realizuje się w wolności, poprzez samoświadomość swojego istnienia i działania. Wolność była i jest tematem przewodnim wszystkich ludzi i wszystkich państw. Relacja zachodząca pomiędzy jednostką a jakąkolwiek społecznością opiera się na założeniu wolności i na zakresach wzajemnych obowiązków, które nie niszczą wolności, ale czynią ją bardziej odpowiedzialną.

Karol Wojtyła - późniejszy papież Jan Paweł II - nawiązując do miłości małżeńskiej i rodzinnej, zwracał uwagę właśnie na odpowiedzialność ${ }^{1}$, zawsze obowiązującą rozumny byt, jakim jest człowiek. Te dwie wartości: wolność i odpowiedzialność powinny iść ze sobą $\mathrm{w}$ parze, $\mathrm{w}$ przeciwnym bowiem razie, wolność zamienia się $\mathrm{w}$ samowolę, natomiast odpowiedzialność bez wolności traci sens.

\section{Wolność osobista}

Wolność jest oparta przede wszystkim na relacjach z innymi. Można też mówić o wolności wobec samego siebie w rozumnie działającej samodyscyplinie, koniecznej w procesie wychowania, kształcenia i doskonalenia się duchowego na przestrzeni całego życia. Relacja z innymi przysługuje i obowiązuje człowieka z racji jego naturalnego powołania społecznego, albowiem człowiek jest bytem społecznym. „Nikt z nas nie żyje dla siebie, ani nie umiera dla siebie", to jasne przesłanie Pisma Świętego, autorstwa św. Pawła z Tarsu² (Rz 14,7). To stwierdzenie i własne doświadczenia życiowe wskazują na godność i znaczenie życia

\footnotetext{
* Tekst ten ukazał się w nr. 14 „Zeszytu o Bożej Opatrzności” wydawanym przez Instytut Papieża Jana Pawła II.

${ }^{1}$ K. Wojtyła, Miłość i odpowiedzialność, Lublin 1986.

${ }^{2}$ Paweł z Tarsu, Paweł Apostoł, Szaweł (ur. ok. 5-10 w Tarsie w Cylicji, zm. ok. 64-67 w Rzymie), Żyd z Tarsu, święty chrześcijański, męczennik. Zwany Apostołem Narodów, choć nie należał do grona dwunastu apostołów, ani nawet do szerszej grupy uczniów Jezusa Chrystusa, towarzyszących Mistrzowi w czasie jego publicznej działalności. Był nawróconym faryzeuszem, który wcześniej prześladował chrześcijan. Autor listów wchodzących w skład Nowego Testamentu, [online:] https://pl.wikipedia.org/wiki/Pawe\%C5\%82_z_Tarsu [dostęp: 24.03.2019].
} 
ludzkiego jako na najważniejsze wartości, w których następuje samorealizacja człowieka będącego częścią wielu społeczności; od rodziny, aż po wielkie organizacje międzynarodowe.

Jan Paweł II mówiąc o godności człowieka, o jego „człowieczeństwie”, rozważał je w dwóch aspektach: filozoficznym i teologicznym. Kierunek filozoficzny nawiązuje do doświadczeń każdego z nas, w przeżywaniu i analizie relacji z naszym światem wewnętrznym (poszukiwanie racji rozumu, racji uczuć i przeżyć wyższych, wiary) i racji teologicznych ${ }^{3}$ opartych na tajemnicy połączenia dwóch natur w Chrystusie: natury Boskiej i natury ludzkiej. Pełne nauczanie o relacji wiary i rozumu znajdziemy w encyklice Jana Pawła II Fides et ratio ${ }^{4}$ (Wiara i rozum).

Konieczność poznawania siebie i relacji międzyludzkich opartych na wartościach: wolności, miłości i prawdzie przynależy każdemu z nas, jako człowiekowi. Jan Paweł II tak to ujmuje: „Zarówno w dziejach Wschodu, jak i Zachodu można dostrzec, że człowiek w ciągu stuleci przebył pewną drogę, która prowadziła go stopniowo do spotkania z prawdą i do zmierzenia się z nią. Proces ten dokonał się - nie mogło, bowiem być inaczej - w sferze osobowego samopoznania: im bardziej człowiek poznaje rzeczywistość i świat, tym lepiej zna siebie, jako istotę jedyną w swoim rodzaju, a zarazem coraz bardziej naglące staje się dla niego pytanie o sens rzeczy i jego własnego istnienia" ${ }^{5}$.

\subsection{Wolność, rozum i wiara}

Sens rzeczy, sens istnienia, w tym człowieka, ukazuje Syn Boży, który przyjął naturę ludzką i w ten sposób, na sposób ludzki i Boski, wskazał ludziom wartość i znaczenie życia i odpowiedzialność za nie, w każdym zakresie bycia: indywidualnego i społecznego. Nie można zatem pomijać jakości życia, sposobów realizacji jednostek i społeczności, bez uwzględnienia wartości wolności. Wszelkie ograniczenia wolności indywidualnej i zbiorowej prowadzą do degradacji, zaprzeczają godności człowieka, a w wypadkach skrajnych prowadzą do konfrontacji ideologicznych, politycznych, a nawet militarnych. Jan Paweł II stwierdza: „To właśnie wiara pozwala każdemu jak najlepiej wyrazić swoją wolność. Innymi słowy, wolność nie wyraża się w dokonywaniu wyborów przeciw Bogu. Czyż można, bowiem uznać, że autentycznym przejawem wolności jest odmowa przyjęcia tego, co pozwala na realizację samego siebie? Wolność, zatem nie tylko towarzyszy wierze jest jej nieodzownym warunkiem" ${ }^{\prime 6}$.

Z powyższych zestawień dotyczących wartości rozumu i wiary, które działają w wolności, wynika wniosek praktyczny: Człowiek może posługiwać się wolnością i akceptować

\footnotetext{
${ }^{3}$ "Prawda, którą Bóg powierzył człowiekowi, objawiając mu samego siebie i swoje życie, jest zatem wpisana w czas $\mathrm{i}$ historię. Została ona oczywiście obwieszczona raz na zawsze w tajemnicy Jezusa z Nazaretu. Stwierdza to w bardzo wymownych słowach Konstytucja Dei verbum: «Skoro zaś już wielokrotnie i wielu sposobami Bóg mówił przez Proroków, na koniec w tych czasach przemówił do nas przez Syna.» (por. Hbr 1,1-2)”, Jan Paweł II, Encyklika Fides et ratio (14.09.1998), 11, [w:] tegoż, Encykliki Ojca Świętego Jana Pawła II, t. 2, red. S. Małysiak, Kraków 1998.

${ }^{4}$ Tamże.

${ }^{5}$ Tamże, s. 1.

${ }^{6}$ Tamże, s. 11.
} 
swoją rozumność i wiarę. Sama wolność staje się drogą życia, a zarazem obowiązkiem odpowiedzialnego działania, wobec siebie i całego otaczającego świata. Człowiek wolny działa, ponieważ ma taką możliwość, a działając staje się bardziej człowiekiem, staje się bardziej ludzki, nie jest obojętny. Działanie ludzkie jest obowiązkiem, ponieważ wynika ono z samej natury wolności. Przeciwieństwem działania jest: brak działania, lenistwo, opieszałość, niechęć do działania, a zatem wolność nie może realizować się w takich antywartościach jak brak działania. W kontekście posiadania wolności degradowałoby to człowieka jako takiego.

W tym kontekście - wolności działania człowieka - warto także przypomnieć wskazania papieża Franciszka podczas Światowych Dni Młodzieży w Krakowie w 2016 r.: „Wstańcie z kanapy i idźcie zmieniać świat". Zmiana świata, odnosi się zarówno do wolnego działania w samostanowieniu, jak i działania na korzyść innych.

\subsection{Wolność działania w Osoba i czyn}

Rozważania na temat wolności znajdujemy u Karola Wojtyły w publikacji Osoba i czyn, gdzie wolność doświadczana przez człowieka świadczy o wyjątkowej właściwości osoby rozumnej, która działa i doświadcza świadomie skutków tegoż działania. Znajdujemy tam następujące wyjaśnienie: „Przedmiotowość samostanowienia oraz chcenia może odpowiadać tylko przedmiotowości poznania. Tylko w swej funkcji obiektywizującej poznanie prowadzi wolę (...). W funkcji zaś subiektywizującej, jako świadomość, poznanie towarzyszy woli, i dopełnia ją w obrębie tej specyficznej struktury, jaką przedstawia osoba"8.

Rozważając zagadnienia wolności dochodzimy do pojęcia osoby. Człowiek jest osoba, to znaczy ma wolę, rozum, może poznawać rzeczywistość obiektywnie i doświadczać tej rzeczywistości przeżywając ją. Takie stwierdzenia wprowadzają nas na drogę filozofii personalistycznej. Zrozumienie takiego rozumowania ułatwia następujący tekst: „W rozważaniach filozoficznych na temat wolności Karol Wojtyła wychodzi od doświadczenia, które - według niego - jest zawsze jakimś zrozumieniem, znajduje odzwierciedlenie w świadomości, a także stanowi treść przeżycia. To doświadczenie, szczególnie dane poprzez czyn, dotyczy również przeżycia dobra i zła moralnego, czyli moralności. Doświadczenia człowieka oraz doświadczenia moralności nie można rozdzielać, ponieważ stanowią one pewną całość, chociaż każde z osobna można oddzielnie badać" ${ }^{\prime}$.

Wolność, jako wartość oraz działanie człowieka w wolności, prowadzi wprost do odpowiedzialności, za którą idzie moralność każdego czynu ludzkiego. Człowiek, jako osoba, jest nie tylko wolny, ale także odpowiedzialny za swój czyn oraz za skutki własnego działania ${ }^{10}$. Nie należy wolności mylić z samowolą z poczuciem bezkarności i obojętnością wobec dobra i ewentualnego zła spowodowanego przez czyn ludzki.

\footnotetext{
${ }^{7}$ K. Wojtyła, Osoba i czyn, Kraków 1969.

${ }^{8}$ Tamże, s. 118.

${ }_{9}$ T. Górka, Rozumienie wolności w myśli filozoficznej Karola Wojtyty, https://prasa.wiara.pl/doc/1445424.Rozumieniewolnosci-w-mysli-filozoficznej-Karola-Wojtyly/5[dostęp: 24.03.2019].

10 "Chodzi więc o wolność, jako rzeczywistość, chodzi o tę wolność, która jest rzeczywistą właściwością człowieka, rzeczywistym też przymiotem jego woli”. K. Wojtyła, Osoba i czyn, s. 120.
} 
Wolność, która nie kieruje się dobrem (oceną moralną czynu) nie jest wolnościa, gdy człowiek wybiera tzw. "mniejsze zło”, traktując daną sytuację jako imperatyw działania w stopniującym się złu. W takim wypadku zmniejsza się odpowiedzialność prawna, ale nie moralna, która nakazuje unikanie zła, w sposób czasem nawet heroiczny.

\subsection{Poznanie prawdy w wolności}

Poznanie ze swej natury dąży do prawdy, czyli do uzyskania rzetelnej, obiektywnej, informacji o swoim przedmiocie. Według definicji wywodzącej się od Arystotelesa, a znanej $\mathrm{w}$ sformułowaniu Tomasza z Akwinu, prawda jest to intencjonalna zgodność rozumu (intelektu) z rzeczą. Prawda i wolność są to dwie wartości, które nawzajem się warunkują i przenikaja, a miejscem ich spotkania jest osoba. Do takiego stwierdzenia upoważnia przede wszystkim relacyjny charakter prawdy i wolności ${ }^{11}$. Nic nie może być prawdziwe, jeśli podawane jest bez wolności, człowiek takiej prawdy nie przyjmuje i podejrzewa ją o fałsz, manipulację i propagandę. Wolność zatem współdziała z innymi podstawowymi wartościami, tj. z miłością pokojem, sprawiedliwością, solidarnością. Nadawanie tym wartościom „ludzkiego oblicza”, tzw. człowieczeństwa wymaga wolności osobistej. Człowiek pragnie i działa w sposób wolny i w ten sposób wyraża swoją godność osoby.

Człowiek pozostaje wolny także w poznawaniu siebie samego. Jest to także jego obowiązek moralny - wolna i prawdziwa relacja z samym sobą. W taki sposób można poznać cechy własnego charakteru, można odkryć wypaczenia w swoim myśleniu i w działaniu. Taka korekta samego siebie dokonuje się poprzez samowychowanie ${ }^{12}$, które trwa przez całe życie. Relacja „ja” wobec samego siebie pomaga w poprawnym poznawaniu siebie, poznawaniu swoich zalet i zarazem słabości oraz w budowaniu postawy nakierowanej na dobro wyrażane w wartościach. Wolna postawa w poznawaniu samego siebie i kształtowania własnego charakteru jest wskazana moralnie. Jest również pozytywnie oceniana przez środowisko społeczne. Dobro jednostki wprost przekłada się na dobro społeczeństwa, w którym jednostka funkcjonuje.

Do samooceny i samowychowania potrzebne są doświadczenia własne, konfrontowane z wzorcami wychowawczymi, powszechnie znanymi, sprawdzonymi przez innych ludzi, a udostępnionymi z motywów dobra wspólnego.

\subsection{Relacja wolności z miłością}

Wartości podstawowe, powszechnie rozpoznawane i wprowadzane w moralne życie człowieka, współdziałają tworząc zwarty zespół norm i zasad postępowania. Dlatego wolność powinna się także realizować w miłości. Miłość jest wartością nadrzędną ale może

\footnotetext{
${ }^{11}$ Zob. Z. Struzik, Wprowadzenie do programu wychowawczego opartego na wartościach wedtug nauczania Jana Pawła II, Warszawa 2017, s. 18.

${ }^{12}$ Jan Paweł II, List do rodzin Gratissimam sane (2.02.1994), 16, [w:] tegoż, Dzieła zebrane, t. 3, Listy, red. P. Ptasznik, Kraków 2007.
} 
być realizowana jedynie z zachowaniem wolności. Do miłości nikogo nie można przymusić, ani siebie, ani innych, bowiem miłość jest dobrowolnym darem.

„Miłość nie oznacza emocjonalnego przemijania czy chwilowego oczarowania, ale wyraża wolę i odpowiedzialną decyzję związania się całkowicie «na dobre i na złe». Jest darem z siebie samego drugiemu człowiekowi" - powiedział Jan Paweł II w swoim przemówieniu w szpitalu po zamachu na placu św. Piotra 13 maja 1981 r. Skoro miłość wyraża wolę, to wolność woli i wolność decyzji staje się podstawą do dawania siebie w darze, a dar może być przekazywany tylko w wolności.

\section{Wolność społeczna}

Wolność społeczna rozpoczyna się od relacji z drugim człowiekiem, te relacje są szczególnie rozbudowane w małżeństwie i rodzinie. Rodziny zaś tworzą społeczności o różnym charakterze: w miejscach zamieszkania, w ośrodkach kształcenia i wychowania, pracy, wypoczynku i zabawy oraz modlitwy (w Kościele). Wszystkie te społeczności oparte są na wolnym wyborze i akceptacji. Wolny wybór dokonuje się w życiu społecznym spontanicznie, ponieważ człowiek naturalnie pragnie relacji z innymi ludźmi będąc istotą społeczną.

„Przynaglany pragnieniem odkrycia ostatecznej prawdy swojego istnienia, człowiek stara się zdobyć pewne elementy uniwersalnej wiedzy, które pozwalają mu lepiej rozumieć samego siebie i coraz pełniej się realizować. Ta podstawowa wiedza bierze początek z zadziwienia, jakie budzi w nim kontemplacja tego, co stworzone: człowiek odkrywa ze zdumieniem, że żyje w świecie i jest związany z innymi istotami podobnymi do siebie, z którymi łączy go wspólne przeznaczenie", stwierdził Jan Paweł $\mathrm{II}^{13}$.

"Człowiek nie żyje sam dla siebie i nie umiera sam dla siebie”, poucza św. Paweł w Liście do Rzymian (Rz 14,7-12). W pierwszym rzędzie ten tekst odnosi się do relacji Bóg-człowiek, a następnie, na zasadzie wolności i miłości, wskazuje na wzajemne powiązanie ludzi jako dzieci Bożych. Dziecięctwo Boże zobowiązuje ludzi wierzących do trwania we wspólnotach i do obdarowywania siebie nawzajem dobrem, które ma znaczenie moralne i religijne zarazem. Okazywanie życzliwości, życie w pokoju i wzajemna służba nie jest przymusem, przeciwnie, dokonuje się z własnej, nieprzymuszonej woli, wynika niejako z natury społecznej człowieka. „Uczyńmy człowieka na Nasz obraz....” „Uczynię mu zatem odpowiednią dla niego pomoc” (Rdz 2,18). Takie są jedne z pierwszych wskazań i motywów życia społecznego człowieka. Wzajemna pomoc nie oznacza poddania i niewolniczej służby. Oznacza równość, współpracę, uznanie jednakowej godności mężczyzny i kobiety. Przyszła zależność, pomoc, dobrowolna miłość jest potwierdzona przez akceptację pierwszego człowieka (czytaj: wszystkich ludzi): „Ta dopiero jest kością z moich kości i ciałem z mego ciała!” (Rdz 2,23).

Wzajemna równość, godność i poznanie drugiego człowieka dokonuje się w sposób wolny. Dwie wolne wole człowieka spotykają się, realizują dialog miłości (małżeństwo), dialog współpracy (miejsca pracy), wymiany przymiotów duchowych (wartości) i materialnych (sprawiedliwy handel, pomoc, bezinteresowne dary).

\footnotetext{
${ }^{13}$ Jan Paweł II, Encyklika Fides et ratio, s. 4.
} 


\subsection{Miłość i płodność małżonków realizowane w wolności}

Naturę stworzenia można rozumiećjako proces ewolucyjny ${ }^{14}$, wynika z niej przeznaczenie określonej płci człowieka do przekazywania życia. Celem związku kobiety i mężczyzny jest wzajemna miłość (dobro przekazywane w formie daru) oraz przekazywanie największego i najważniejszego daru jakim jest życie. Zachodzi wówczas nadzwyczajna relacja, nowa za każdym razem i niepowtarzalna, relacja macierzyńska ${ }^{15}$, ojcowska i rodzicielska.

Człowiek jest stworzony, ukształtowany chromosomowo ${ }^{16}$, gonadycznie ${ }^{17}$, rozwojowo (dojrzewanie płciowe ${ }^{18}$ ), wychowawczo i kulturowo w długim procesie ukierunkowanym do przekazywania życia, jest naturalnie nakierowany do roli matki albo ojca. I tak się dzieje z pokolenia na pokolenie. Sensem bycia kobieta, z natury i powołania, jest mężczyzna, a sensem bycia mężczyzną $\mathrm{z}$ natury i powołania, jest kobieta. Z punktu widzenia filozoficznego i fizjologicznego wszelkie działania przeciwne są nielogiczne! Wolna wola człowieka jest zobowiązana do decyzji logicznych, akceptacji praw natury, które działają logicznie, w przeciwnym bowiem razie prowadzić to może do zachowań absurdalnych.

Kultura ludzka, wraz z pochodzącą z prawa naturalnego, społecznego i religijnego rodziną, narodem i państwem, ukształtowały i nadal kształtują formy życia ludzkiego w małżeństwie i rodzinie. Formowanie się małżeństw i rodzin dokonuje się z zachowaniem pełnej dobrowolności i wolności, z zachowaniem godności mężczyzny i kobiety. Każda decyzja narzeczonych o wzajemnym trwałym związku oparta jest na osobistym i publicznym zadeklarowaniu własnej dobrej woli, aby być mężem i żoną. W dalszej kolejności rodzice decydują w sposób wolny ile razy i kiedy nowe życie przekazywać.

Wolność związków małżeńskich jest rozpoznawana i stwierdzana w podstawowym nauczaniu Kościoła rzymskokatolickiego, który podnosi związek małżeński ludzi ochrzczonych do rangi sakramentu. Wyrażenie zgody małżeńskiej w sposób wolny

\footnotetext{
14 "Człowiek - został stworzony na obraz i podobieństwo Boże (por. Rdz 1,28-29). Soborowa konstytucja Gaudium et spes wspaniale przedstawiła tę doktrynę, stanowiącą jeden z fundamentów myśli chrześcijańskiej. Przypomniała, że człowiek jest «jedynym na ziemi stworzeniem, którego Bóg chciał dla niego samego» (n. 24). Jest osobą (...). Cały człowiek, włącznie z ciałem, jest obdarzony taką godnościa, ponieważ posiada duszę duchową. Pius XII zwrócił uwagę na tę istotną kwestię: jeśli ciało ludzkie bierze początek z istniejącej wcześniej materii ożywionej, dusza duchowa zostaje stworzona bezpośrednio przez Boga: animas enim a Deo immediate creari catholica fides nos retinere iubet". Humani generis, AAS42 [1950], 575, n. 5. Dnia 22 października 1996 r. Jan Paweł II skierował przesłanie do uczestników sesji plenarnej Papieskiej Akademii Nauk.

${ }^{15}$ Zob. Z. Struzik, Macierzyństwo wyrazem miłości ojczyzny w nauczaniu papieskim, Zeszyt o Opatrzności Bożej, 13, Warszawa 2019.

${ }^{16}$ Łącznie kariotyp człowieka tworzą 23 pary chromosomów. Osobnik posiadający chromosomy XX jest płci żeńskiej, natomiast osobnik z jednym chromosomem $X$ i jednym chromosomem $Y$ - będzie płci męskiej. $X$ jest większy od Y i zawiera więcej genów. Y zawiera gen SRY determinujący płeć męską, https://www.google.com/ search?q=chromosom + p \%C5\%82ci\&oq=hromzom + p $\% C 5 \% 82$ ci\&aqs=chrome.1.69i57j015.20731j0j9\&sourceid=chrome\& ie=UTF-8[dostęp: 31.03.2019].

${ }^{17}$ Gonada, gruczoł płciowy, gruczoł rozrodczy - występujący u zwierząt narząd płciowy produkujący męskie bądź żeńskie komórki rozrodcze (gamety). Gonady umożliwiają rozmnażanie płciowe, https://www.google.com/search?q=g onady+co+to\&oq=gonady+\&aqs=chrome.1.69i57j015.5109j0j7\&sourceid=chrome\&ie=UTF-8 [dostęp: 31.03.2019].

${ }^{18}$ Pokwitanie, dojrzewanie płciowe (łac. pubertas) - okres procesu dojrzewania u człowieka, trwający ok. 4-5 lat, w którym następuje rozwój drugo- i trzeciorzędnych cech płciowych.
} 
i publiczny stanowi akt zawiązania wspólnoty: mężczyzny i kobiety w sposób trwały. „Zgoda małżeńska, stanowiąca akt woli, przez który strony wzajemnie się sobie przekazują i przyjmują w celu ustanowienia małżeństwa ${ }^{19}$ (jako wspólnoty całego życia z natury swojej skierowanej ku dobru małżonków oraz ku zrodzeniu i wychowaniu potomstwa), jest aktem ludzkim (Actus humanus), a więc rozumnym i wolnym"20.

Czyn ludzki, akt ludzki, aczkolwiek tylko ludzki, ma charakter stały, obowiązuje człowieka, zgodnie z treścią zobowiązania (przysięgi małżeńskiej) przez całe życie, pomimo wielu czynników i zmian zewnętrznych, które nastąpią w przyszłości. Wolna wola zainteresowanych nie tylko ma się podporządkowywać zmiennym rzeczywistościom, powinna ona stale dobrowolnie wybierać dobro, wspólnotę raz zadecydowaną.

\subsection{Człowiek a wolność pracy}

Stawiamy pytanie: Czy człowiek z natury swej wolny może być zmuszany do pracy? Z doświadczenia wiemy, że każda praca łączy się z wysiłkiem intelektualnym i fizycznym, a $\mathrm{w}$ organizmie ludzkim, mimo że płynie w nim czerwona krew, nie jest ona robotnicza ${ }^{21}$. Poprzez osiągnięcia naukowe i techniczne trud fizycznej pracy znacznie się zmniejsza, przynajmniej w krajach o wysokim rozwoju technologicznym. Niemniej jednak, do wykonywanej pracy niezbędne jest odpowiednie wykształcenie, częstokroć kosztowne i długoletnie. Wiele prac ma charakter monotonny, powtarzający się i działa niekorzystnie na samopoczucie pracowników.

Teologia biblijna głosi prawdę o naturalnym powołaniu człowieka do pracy, zawartym w wezwaniu Stwórcy: „Czyńcie sobie ziemię poddaną!”; „Bądźcie płodni i rozmnażajcie się, abyście zaludnili ziemię i uczynili ją sobie poddaną; abyście panowali nad rybami morskimi, nad ptactwem powietrznym i nad wszystkimi zwierzętami pełzającymi po ziemi" (Rdz 1,28). Stworzenie człowieka rozumnego i zarazem fizycznego w naturalny sposób skłaniało jego przeznaczenie do pracy, jako sposobie na życie doczesne.

Jan Paweł II naucza w encyklice Laborem exercens, że „praca jest jednym z tych aspektów, aspektem odwiecznym i pierwszoplanowym, zawsze aktualnym i wciąż na nowo domagającym się, by o niej myśleć i świadczyć. Coraz to nowe, bowiem powstają pytania i problemy, coraz nowe rodzą się nadzieje, ale także obawy i zagrożenia, związane z tym podstawowym wymiarem ludzkiego bytowania, z którego życie człowieka jest zbudowane, na co dzień, z którego czerpie właściwą sobie godność"22.

Niewątpliwie praca jest zjawiskiem społecznym, które realizuje się w wielu relacjach międzyludzkich opartych na wymianie myśli i działań dążących do stworzenia sobie warunków codziennej egzystencji. Działania związane z pracą determinują człowieka

\footnotetext{
${ }^{19}$ Kan. 1057 § 2 Kodeks Prawa Kanonicznego.

${ }^{20}$ W. Góralski, Wolność wewnętrzna a ważność małżeństwa kanonicznego, Prawo Kanoniczne. Kwartalnik prawno-historyczny, 56, 3, 2013, s. 55-81.

${ }^{21}$ Zob. W treści robotniczej piosenki „Czerwony sztandar” znajdziemy słowa: „(...) a na nim robotnicza krew....”.

${ }^{22}$ Jan Paweł II, Encyklika Laborem exercens (14.09.1981), 1, [w:] tegoż, Encykliki Ojca Świętego Jana Pawła II, t. 1, red. S. Małysiak, Kraków 1996.
} 
w zakresie kodeksów pracy, możliwości zmiany pracy, a także zdobywania pracy niezbędnej do utrzymania siebie i własnej rodziny. Z jednej strony praca staje się powołaniem, a z drugiej ma charakter konieczności, którą człowiek przyjmuje dobrowolnie na zasadzie sprawiedliwości społecznej. Dobra otrzymywane od innych pracujących wskazują na konieczność oddania własnego czasu, wysiłku i zdolności na rzecz innych. Z czasem człowiek może całkowicie zaakceptować swoją pracę, odkryć w niej wiele dobra i poświęcić się jej z całym oddaniem. Taka postawa świadczy o dojrzałym i godnym człowieczeństwie, które wypełnia czas życia w sposób pożyteczny i produktywny dla siebie samego i dla innych.

Praca i związany z nią człowiek ma charakter społeczny i wchodzi w zakres duchowości i moralności ludzkiej, która domaga się wskazań autorytetów, tak ogólnoludzkich, jak i religijnych. Jan Paweł II stwierdzał, że: „Problem pracy należał od początku do nauczania Kościoła, jego nauki o człowieku, o życiu społecznym, a w szczególności nauki o moralności społecznej, którą wypracowywał wedle potrzeb różnych epok"23.

Nauka społeczna Kościoła na przestrzeni wieków, a szczególnie w ostatnich latach, stara się wskazywać podstawowe wartości oraz podstawowe normy i zasady dotyczące pracy ludzkiej, dostosowując nauczanie do systemów politycznych, gospodarczych i międzynarodowych. W nauczaniu społecznym zawsze podkreślana jest godność pracującego człowieka, sprawiedliwość w organizowaniu pracy, sprawiedliwość w wynagradzaniu za pracę, bezpieczeństwo pracy oraz prawo do odpoczynku po spełnieniu obowiązku pracy.

Jan Paweł II podkreślał godność pracującego człowieka w słowach: „Człowiek, dlatego ma czynić sobie ziemię poddana, ma nad nią panować, ponieważ jako «obraz Boga» jest osoba, czyli bytem podmiotowym uzdolnionym do planowego i celowego działania, zdolnym do stanowienia o sobie i zmierzającym do spełnienia siebie. Jako osoba jest człowiek podmiotem pracy. Jako osoba pracuje, wykonuje różne czynności przynależące do procesu pracy, a wszystkie one, bez względu na ich charakter, mają służyć urzeczywistnianiu się jego człowieczeństwa" ${ }^{24}$.

Z powyższych rozważań wynika, że wolność ludzka może i powinna wyrażać się w podejmowaniu pracy z obowiązku naturalnego i stanowić drogę rozwoju i doskonalenia siebie i innych. Dobra wynikające z pracy winny być dzielone sprawiedliwie z zachowaniem wartości: wolności, sprawiedliwości, a nawet miłości. Miłością i troską należy w życiu społecznym objąć tych, którzy pracować nie mogą ze względu na wiek, chorobę, a także ze względu na źle funkcjonujące stosunki pracy w danym państwie (np. bezrobocie).

\subsection{Wolność trwania w wartościach duchowych i materialnych}

Człowiek jako osoba i zarazem dziecko Boże porusza się i działa, tworzy, myśli i planuje, zdobywa doświadczenia, uczy się i poznaje świat własny, świat zewnętrzny i świat duchowy. Dzięki duchowości i wolności możemy hierarchizować wartości, zarówno materialne, jak i duchowe.

\footnotetext{
${ }^{23}$ Tamże, s. 3.

${ }^{24}$ Tamże, s. 6.
} 
Powstaje pytanie: Czy konieczne jest poznawanie wyższych wartości moralnych oraz poszukiwanie racji ich istnienia? Można przecież zatrzymać się nad samą materia, którą można rozumieć tak, że sama z siebie wytworzyła ludzką inteligencję. Popełnia się jednak wówczas metodologiczny błąd, mianowicie taki, że to materia wytwarza ducha. Powstaje wtedy sprzeczność logiczna, w której człowiek uważa się za autora całej rzeczywistości. Jednak sentencja stwórcza świata i człowieka w opisie biblijnym przebiegała inaczej. To człowiek i jego natura ulegała ewolucji.

Poszukiwanie racji duchowych istnienia człowieka prowadzi do religii naturalnych, które odpowiadają na pytania o sens życia i umierania bytu rozumnego - duchowego, to znaczy człowieka. Religie objawione są wyrazem dialogu Boga z człowiekiem, Bóg mówi do nas przez słowo i przez akty zbawcze realizowane w Synu Bożym - Jezusie Chrystusie. Wobec faktów zbawczych i obecności Syna Bożego na ziemi, wola nasza w wolności rozpoznaje wielkość i wszechmoc Bożą. Wtedy stajemy się wierzącymi.

\subsection{Wolność wyboru religii. Czy wszystkie religie są prawdziwe?}

Jan Paweł II dokonał określonej syntezy wiary, która przynależy do natury człowieka, zapraszając przedstawicieli różnych religii i wyznań na wspólne spotkanie w Asyżu ${ }^{25}$. Powstała wątpliwość: Jak takie spotkanie ma się do prawdziwości religii objawionej?

Czy jest możliwa wspólna modlitwa z wyznawcami innych religii: monoteistami, politeistami, panteistami albo transcendentalistami? Kard. Joseph Ratzinger, prefekt Kongregacji Doktryny Wiary, odpowiada na to pytanie w swej książce Fede, verita, tolleranzaIl cristianesimo e le religioni del mondo (Wiara, prawda, tolerancja-chrześcijaństwo i religie świata), podając jednocześnie warunki wspólnej modlitwy ${ }^{26}$. „Trzeba rozróżnić między modlitwą wieloreligijną i międzyreligijną"27 - pisze kard. Ratzinger. Modlitwy o pokój w Asyżu, do których wzywał Jan Paweł II, są „,wieloreligijne”, gdyż wszyscy uczestnicy modlą się w tym samym czasie, ale w różnych miejscach.

Uczestnicy „wiedza, że ich sposób rozumienia boskości, a stąd i sposób zwracania się do Niej, jest tak różny, że wspólna modlitwa byłaby fikcją, nie byłaby prawdziwa"28. Natomiast w modlitwach „międzyreligijnych” ludzie z rożnych tradycji religijnych modlą się razem. „Czy jest możliwe, by czynić to w sposób zgodny z prawdą i uczciwy?" Jeżeli takie modlitwy międzyreligijne są organizowane, wymaga to spełnienia trzech warunków - podkreśla z naciskiem kard. Ratzinger. „Po pierwsze: musi być jasne, że modlitwa jest zanoszona do jednego, osobowego Boga. Po drugie: musi być ustalona intencja modlitwy, która nie

\footnotetext{
${ }^{25}$ Jan Paweł II zorganizował 27.10.1986 r. spotkanie wszystkich religii w franciszkańskiej bazylice w Asyżu.W ten sposób urzeczywistnił swe pragnienie, zapraszając przedstawicieli głównych religii świata i wyznań chrześcijańskich do Asyżu, aby w wielu językach modlić się o pokój. W mieście św. Franciszka spotkali się chrześcijanie, żydzi, muzułmanie, hinduiści, buddyści, przedstawiciele religii ludów pierwotnych z całego świata, przekonani, że prawdziwy pokój można osiągnąć jedynie poprzez głęboką relację z Bogiem na modlitwie.

${ }^{26} \mathrm{~J}$. Ratzinger, Fede, verita, tolleranza - Il cristianesimo e le religioni del mondo, Siena 2003.

${ }^{27}$ Tamże.

${ }^{28}$ Tamże.
} 
przeciwstawia się naszemu Ojcu. Po trzecie, musi być podkreślone, że dla chrześcijan Jezus Chrystus jest jedynym Zbawicielem wszystkich ludzi"29.

Relacje Bóg - człowiek zawsze są oparte na wolności. Bóg nie pragnie mieć z wyznawców niewolników, dobra wola człowieka umożliwia dotarcie do Boga, a nawet pokochanie Go, bo Bóg jest Miłością! Trudno też z własnej wolnej woli czynić argument, sprzeczny z wolą Bożą. W tym wypadku dwie wolne wole: Boska i ludzka łączą się i człowiek jest dobrowolnie religijny.

Jan Paweł II zredagował encyklikę o wierze: Fides et ratio, papież Benedykt XVI encyklikę Deus Caritas est ${ }^{30}$ (Bóg jest Miłościa) oraz encyklikę o nadziei Spe Salvi facti sumus (W nadziei już jesteśmy zbawieni ${ }^{31} \mathrm{Rz}$ 8,24). Papież Franciszek natomiast odniósł się do cnoty wiary i nadziei w encyklice Lumen fidei ${ }^{32}$ (Światło wiary), a także adhortacji o miłości małżeńskiej i rodzinnej Amoris laetitia ${ }^{33}$ (Radość miłości). Mamy zatem pełny wykład wiary zawarty w trzech teologicznych cnotach: wierze, miłości i nadziei.

\subsection{Caritas Boga a wolność człowieka}

Benedykt XVI naucza w encyklice Deus Caritas est, że Bóg jest Miłościa, a szczególnie jest to miłość życzliwa, opiekuńcza, pragnąca dobra doczesnego i wiecznego dla człowieka.

„«Bóg jest miłościa kto trwa w miłości, trwa w Bogu, a Bóg trwa w nim»”. (1J 4,16). Słowa z Pierwszego Listu świętego Jana wyrażaja, ze szczególną jasnościa, istotę wiary chrześcijańskiej: chrześcijański obraz Boga i wynikający z niego obraz człowieka i jego drogi. Oprócz tego, w tym samym wierszu, św. Jan daje nam jakby zwięzłą zasadę chrześcijańskiego życia: „«Myśmy poznali i uwierzyli miłości, jaką Bóg ma ku nam»”34. Skoro Bóg jest Miłościa, a człowiek jest stworzony do miłości, wobec tego przyglądamy się sobie wzajemnie z miłościa, aby się poznać i pokochać. Z natury Bożej wynika, że to On nas pierwszy pokochał, a my w wolny sposób (miłość nie przyjmuje nakazu, ani przymusu), odpowiadamy na tę miłość. Jesteśmy stworzeni na obraz Boga, czytamy o tym w I rozdziale Księgi Rodzaju: „Uczyńmy człowieka na nasz obraz, podobnego nam..." (Rdz 1,26). Zapewne to podobieństwo jest duchowe - mamy duszę nieśmiertelną. Podobieństwo cielesne zaś, dokonało się w kierunku przeciwnym. To Jezus Chrystus Syn Boży przyjął naturę ludzką i podniósł ją do godności zbawienia. Normą i zasadą życia człowieka pozostaje doskonalenie się na "obraz Boga”, inaczej mówiąc uświęcenie się, poprzez miłość w doczesnym i wiecznym życiu. „Istnieje jakaś relacja między miłością i Boskością: miłość obiecuje nieskończoność, wieczność - jakąś rzeczywistość wyższą i całkowicie inną w stosunku do codzienności naszego istnienia"35, stwierdza Benedykt XVI.

\footnotetext{
${ }^{29}$ Tamże.

${ }^{30}$ Benedykt XVI, Encyklika Deus Caritas est (25.12.2005), Radom 2006.

${ }^{31}$ Benedykt XVI, Encyklika Spe Salvi (30.11.2007), Poznań 2007.

${ }^{32}$ Franciszek, Encyklika Lumen fidei (5.07.2015), Kraków 2013.

${ }^{33}$ Franciszek, Encyklika Amoris laetitia (19.03.2016), Wrocław 2016.

${ }^{34}$ Benedykt XVI, Encyklika Deus Caritas est, s. 1.

${ }^{35}$ Tamże, s. 5.
} 
Wobec wielkości woli Boga a wolą człowieka jest niezmierzona różnica, ale człowiek wolny i świadomy swej miłości do Boga też ma unikatową i nadzwyczajną miłość opartą na wolności. Człowiek musi chcieć kochać Boga z samej tylko racji, że On istnieje. Także z racji swojej ludzkiej natury, która w sposób pośredni przybliża i objawia Boga.

\section{Wolność państwowa}

Państwo opiera się i realizuje swoje zadania na podstawie wolności obywateli, chociaż nieustannie tę wolność „zamyka” w ramy prawa. Z historycznego punktu widzenia, proces doskonalenia się prawa i osiąganie poziomu praw demokratycznych zajęło ludzkości wiele wieków, walk, poświęceń, pracy naukowej oraz doświadczenia, szczególnie w okresie rozwoju społecznych środków przekazu. Dzięki takim środkom ludzie z różnych stron świata wzajemnie się poznają i pośrednio również wpływają na siebie.

\subsection{Budowanie wspólnot narodowych}

Jan Paweł II wskazuje w swojej adhortacji Ecclesia in Europa ${ }^{36}$, że państwa Europy powstały dzięki dziedzictwu chrześcijańskiemu: „Nie dziwią zatem zbytnio próby nadania Europie oblicza wykluczającego dziedzictwo religijne, a w szczególności głęboką duszę chrześcijańską przez stanowienie praw dla tworzących ją ludów, w oderwaniu od ich życiodajnego źródła, jakim jest chrześcijaństwo" ${ }^{37}$. Zarówno motyw scalający Europejczyków, jak i rozpowszechniający się agnostycyzm, wskazują na pełną dobrowolność człowieka historycznego, który raz docenia, a następnie odrzuca objawienie Boże. Mimo wszystko jednak korzysta z praw człowieka rozpoznanych i nauczanych przez Kościół.

O kulturowych aspektach tworzenia się wspólnoty europejskiej mówi także współczesna literatura, a mianowicie: „Czynniki polityczne, gospodarcze i ideowe spowodowały, że w krajach Europy zaczęły pojawiać się plany zinstytucjonalizowania współpracy między państwami. Było to możliwe dzięki podobnej strukturze kulturowej, filozoficznej i myśli politycznej. Konsekwencją tego były podobne systemy wartości. Dziedzictwo duchowe i moralne kultury europejskiej opiera się przecież na niepodzielnych i uniwersalnych wartościach ludzkiej godności, wolności, równości i solidarności"38.

Do wspomnianych wartości: wolności, równości, solidarności należy dodać sprawiedliwość i pokój. Bez sprawiedliwości nie mogą układać się poprawne stosunki i zależność człowieka od człowieka. Wszyscy wzajemnie jesteśmy sobie potrzebni. Sprawiedliwy podział pracy i owoców każdej pracy gwarantuje pokój na każdym poziomie życia społecznego: rodziny, narodu, państwa i pomiędzy państwami.

\footnotetext{
${ }^{36}$ Jan Paweł II, Adhortacja Ecclesia in Europa, (28.06.2003), [w:] tegoż, Adhortacje Apostolskie Ojca Świętego Jana Pawła II, t. 2, red. M. Romanek, Kraków 2006.

${ }^{37}$ Tamże, s. 7.

${ }^{38}$ Por. F. Gołembski, Kulturowe aspekty integracji europejskiej, Warszawa 2009.
} 
Dopiero w takim zestawieniu manifestuje się godność człowieka, kiedy wszystkie wyższe wartości wspólnie są respektowane, kultywowane i praktycznie wprowadzane w życie.

Do natury człowieka przynależy cnota nadziei, która manifestuje się głębokim zaufaniem do Boga i ludzi. Jan Paweł II stwierdza: „Rozwijanie wzajemnych kontaktów, współpraca i wymiana na różnych poziomach tworzą krok za krokiem nową kulturę, a nawet świadomość europejską, która - jak ufamy - wzbudzi zwłaszcza wśród młodzieży uczucia braterstwa i wolę solidarności"39. Wartość solidarności ujawnia się najbardziej w czasie zagrożeń, wspólnych niebezpieczeństw oraz w budowaniu społeczeństwa sprawiedliwego opartego na relacjach demokratycznych, w których każdy ma jednakowe prawa i obowiązki.

\subsection{Wolność narodowa polska}

O prawach i obowiązkach społeczności narodowej nauczał Jan Paweł II podczas swoich pielgrzymek apostolskich do Polski. Jan Paweł II jako Ojciec Święty pielgrzymował do Polski osiem razy: I pielgrzymka (2-10 czerwca 1979), II pielgrzymka (16-23 czerwca 1983), III pielgrzymka (8-14 czerwca 1987), IV pielgrzymka (1-9 czerwca, 13-20 sierpnia 1991), V pielgrzymka (22 maja 1995), VI pielgrzymka (31 maja - 10 czerwca 1997), VII pielgrzymka (5-17 czerwca 1999), VIII pielgrzymka (16-19 sierpnia 2002). Każda z tych wizyt była realizowana w taki sposób, aby objąć swoim działaniem i nauczaniem cały obszar Polski i dotrzeć do możliwie szerokich mas społeczeństwa. Wizyty te miały charakter religijny, koncentrowały się wokół Kościołów diecezjalnych. Stan społeczeństwa polskiego na przestrzeni lat 1979-2002 zmieniał się wewnętrznie, gospodarczo i politycznie, jednak Jan Paweł II potrafił duchowo i duszpastersko dostrzegać te zmiany, a nawet je inspirował.

I pielgrzymka Jana Pawła II przebiegała pod hasłem: "Gaude Mater Polonia” „Ciesz się, Matko Polsko". Jej celem był udział papieża w obchodach 900. rocznicy śmierci św. Stanisława - patrona Polski. Padły wtedy znamienne słowa skierowane do Polaków żyjących w ramach i „rękach reżimu” sowieckiego. „Niech zstąpi Duch Twój! Niech zstąpi Duch Twój i odnowi oblicze ziemi. Tej ziemi!"

II pielgrzymka odbyła się w okresie stanu wojennego. Pielgrzymka przebiegała pod hasłem: „Pokój Tobie, Polsko - Ojczyzno moja!” Miesiąc po papieskiej pielgrzymce do Ojczyzny (22 lipca 1983 r.) gen. W. Jaruzelski zniósł w Polsce stan wojenny.

III pielgrzymka przebiegała pod hasłem: „Do końca ich umiłował”. Tematyka homilii papieskich podczas tej wizyty koncentrowała się wokół Eucharystii. Społeczeństwo polskie odnowiło w sobie ducha religijnego oraz otrzymało wykład o obecności Chrystusa w sakramencie Eucharystii. Człowiek wierzący nigdy nie jest sam i nie jest opuszczony przez Boga-Zbawiciela.

IV pielgrzymka pod hasłem: „Bogu dziękujcie, ducha nie gaście” była pierwszą pielgrzymką do wolnej Polski. Głównym celem tej wizyty było przewodniczenie obchodom VI Światowego Dnia Młodzieży, które miało miejsce w Częstochowie.

\footnotetext{
${ }^{39}$ Jan Paweł II, Adhortacja Ecclesia in Europa, 12.
} 
V pielgrzymka była najkrótszą i nieoficjalną wizytą Jana Pawła II w Polsce. Trwała tylko jeden dzień. Hasło wizyty w brzmiało: „Zło dobrem zwyciężaj”. Trwało budowanie nowej rzeczywistości gospodarczej i politycznej w naszej Ojczyźnie, wymagało to przypomnienia, aby stosować chrześcijańską zasadę wzajemnego godzenia się społeczeństwa.

VI pielgrzymka przebiegała pod hasłem: „Chrystus wczoraj, dziś i na wieki”. Umocnienie wiary w Chrystusa dawało społeczeństwu polskiemu poczucie bezpieczeństwa doczesnego, wiara stawała się autentyczna i zmieniała postawy i zachowania moralne wielu grup społecznych.

VII pielgrzymka miała hasło: „Bóg jest miłością”. Podczas tej pielgrzymki Jan Paweł II rozważał przede wszystkim 8 ewangelicznych błogosławieństw. Wzywał także do nawrócenia w obliczu nadchodzącego Wielkiego Jubileuszu chrześcijaństwa. Miłość Boga rozlana w sercach ludzkich potrafiła kształtować 2 tysiące lat kultury wielu narodów na wszystkich kontynentach.

Hasłem ostatniej pielgrzymki Jana Pawła II do Polski było: „Bóg bogaty w miłosierdzie”. Głównym celem pielgrzymki było poświęcenie Sanktuarium Bożego Miłosierdzia w Krakowie-Łagiewnikach. Miłosierdzie Boże wspiera naród polski, a religijność Polaków stwarza wielkie perspektywy życia $\mathrm{w}$ wierze, nadziei i wzajemnej miłości dla następnych pokoleń tego ukochanego przez Maryję - Matkę Syna Bożego, narodu.

\section{Podsumowanie}

Wolność jest dana człowiekowi, jako dar i zadanie. W wolności mamy działać jako ludzie, dzieci Boże, dzieci Kościoła, aby stawać się świadomymi i wolnymi czcicielami i wykonawcami woli Bożej. Życie w wolności zobowiązuje do odpowiedzialności za siebie i innych, a także sięga do odpowiedzialności za przyszłe pokolenia Polaków i innych narodów, które w pokoju pragną żyć w Europie i na świecie. 